\title{
The Diagnostics of Motor-Wheel Gears of Quarry Dump Trucks Based on Bearing Wear Monitoring
}

\author{
Kudrevatykh Andrey. V. \\ T. F. Gorbachev Kuzbass State Technical University \\ Kemerovo, Russian Federation \\ kav.ea@yandex.ru
}

\begin{abstract}
The article proposes a method of diagnostics of the actual technical condition of the motor-wheel gear of pit dump trucks. It allows monitoring of the wear of the bearing assemblies, and also to control the parameters of units upon achieving the maximum permissible meanings.

Application of this method allows to prevent failure of the motor wheel gear of a dump truck and to carry out scheduled preventive measures on replacement of the worn bearing.

Through this method, the motor-wheel gear unit will not operate with the gaps exceeding the allowable limits. It will prevent its failure and will contribute to the following qualitative improvements: operational control of the state of a quarry dump truck; constant monitoring of the condition of the gear unit during its operation; longer intervals between scheduled maintenance and repair; reducing unplanned downtime of the equipment; a decrease of the current repair costs; protection of dump trucks from accidents (in case of sudden failure of motorwheel gear); savings on the purchase of new parts and repair work as a result of preventive measures.
\end{abstract}

Keywords: diagnostics, wear, pit dump truck, gear, bearing.

\section{INTRODUCTION}

The review of the published works devoted to increase of durability and reliability of automotive vehicles has shown the existence of rather wide range of researches in this field.

Artamonov P. B.[1], Bazhenov Yu. B.[2], Boyarshinov A. L. [3], Goyeva V. B.[4], Konyushevsky A. B.[5], Kuzmin N. A. [6], Kupriyanov N.C.[7], Makhalov M.S.[8], Ogorodnov S. M.[9], Trukhanov V.M.[10], Faskhiyev H.A. [11], Yakhyev N.Ya. [12], and other scientists have been recently involved in studying the issues of reliability and durability of automotive vehicles.

The majority of works is devoted to wear and reliability of details and mechanisms of automobile engines. Berstein A. I. [13], Gasselberg B.C.[14], Goncharov A.A. [15], Kalimullin R. F. [16], Panachev I.A. [17] are working on the problem.

But, the analysis of the reasons of unplanned idle times of dump trucks has shown that the most significant (by the number of failures, labor input of maintenance, expenses of the material and workforce) are the failures of the mechanical system connected with breakages of a metal structures. Low indicators of reliability and durability of mining transport vehicles are connected, first of all, with the low level of their repair technological effectiveness. The greatest share of downtime is caused by failures of motors wheels gears.
In recent years, a great amount of studies is devoted to improvement of reliability of a dump truck motor wheel gear. In most cases researchers work with the indicators received on the basis of spent oil (the method of the spectral analysis of oil emission is used) $[17,18,19]$ as it is less expensive and laborconsuming.

But, despite the obvious advantages of this method, the information on the technical condition of a motor wheel gear of a dump truck can be obtained only after the analysis of the spent oil while the primary diagnostic parameter is the change of the gap in the bearing.

Application of the diagnostics method of the actual technical condition of a dump truck motor wheel gear based on monitoring of the change in the gap between the bearing and the thrust washer will allow to prevent the wear of the gearings and the extreme concentration of metal in oil.

\section{MethodS}

The corner stone of the research is based on the measuring equipment allowing to define a gap size between the bearing and the thrust washer to ensure exact engagement of a gearing pair, and to avoid an excessive loading of the bearings.

The purpose of the work consists in the development of the diagnostics method of the actual technical condition of the motor wheel gear of dump trucks. It allows monitoring of the bearing wear and controlling of the parts parameters when they achieve maximum allowable limits.

The dump truck motor wheel gear is the object of research.

\section{RESUlts}

The developed method of diagnostics of the actual technical condition of a dump truck motor wheel gear by controlling the gap between the bearing and the thrust washer allows:

1) to control the gap between the bearing and the thrust washer within the standard value;

2) to define the critical condition of the gap between the bearing and the thrust washer in time to make adjustment and prevent the failure of a dump truck motor wheel gear;

3 ) to eliminate any growth of an extreme concentration of metal in oil. 


\section{DISCUSSIONS}

The technical diagnosis is a constituent part of the technological processes. In the planned preventative maintenance system, the quarry dumps are obliged to undergo a preventive repair in the prescribed amount of work after a certain time. An individual approach to each unit is absent. However, there is a need for such an approach, as even during the exploitation of the quarry dump trucks under the same conditions and after the same hours of operation, the technical condition of each of them may differ greatly due to a number of reasons (the individual characteristics of the dump, the quality of driving, maintenance, etc.). All the operations envisaged by a rigid scope of maintenance work may be necessary for each dump truck.

The implementation of these «unnecessary» activities leads, on the one hand, to the incomplete implementation of the individual properties of the dump truck increasing maintenance costs. On the other hand, it does not contribute to the improvement of its technical condition. On the opposite, a frequent intervention in the operation of joints contributes to an increased wear of the mating surfaces, the appearance of damaged fasteners and sealing. A significant loss of human and material resources is also associated with a large volume of repair effects caused by untimely detection of failures.

The fullest use of individual capacities of dump trucks and ensuring a high efficiency during operation can be implemented due to the widespread introduction of technical condition diagnostics of the actual state of the object into the process of maintenance and repair.

At the mines, the technical condition of a dump truck motor wheel in the process of operation is mainly determined by: external examination; at the hearing (noise operation), and by vibration; on the degree of the unit body heating.

Visually, an oil leakage can indicate a worn or damaged cuff as well as the appearance of pores and cracks in the housing, the cap or wheel motor hub. If vibrations or increased noise levels at work occur, accidental breakage or loose parts can be identified. According to the degree of heating misalignment of bearings or change of level of oil in the gearbox can be determined [20].

One of the most important parameter of the reliability of the gear motor is a gap between the wheel bearing and the thrust washer (Figure 1).

One of the most important parameter of the safety of the motor wheel reduction gear is the gap between the bearing and the thrust washer of the number. At present, the norm for an admission to the operation of the gearbox is a gap of $0.03 \mathrm{~mm}$ [21]. The dismantling of the gearbox is carried out after 3 years. During this time, the wear is $0.5-1 \mathrm{~mm}$ and at the value of $1.03 \mathrm{~mm}$ the repairs must be carried out. Therefore, it is advisable to carry out diagnostics on the actual state of the motor-gear wheel, which allows to monitor the wear of the bearing assemblies, and also to control the parameters upon achieving the maximum permissible values. Diagnostics consists of installing a special sensor in the thrust washer of the bearing of the motor-wheel gear. The sensor is able to send a signal directly in time to the dump truck cab about achieving of the maximum allowable parameters.

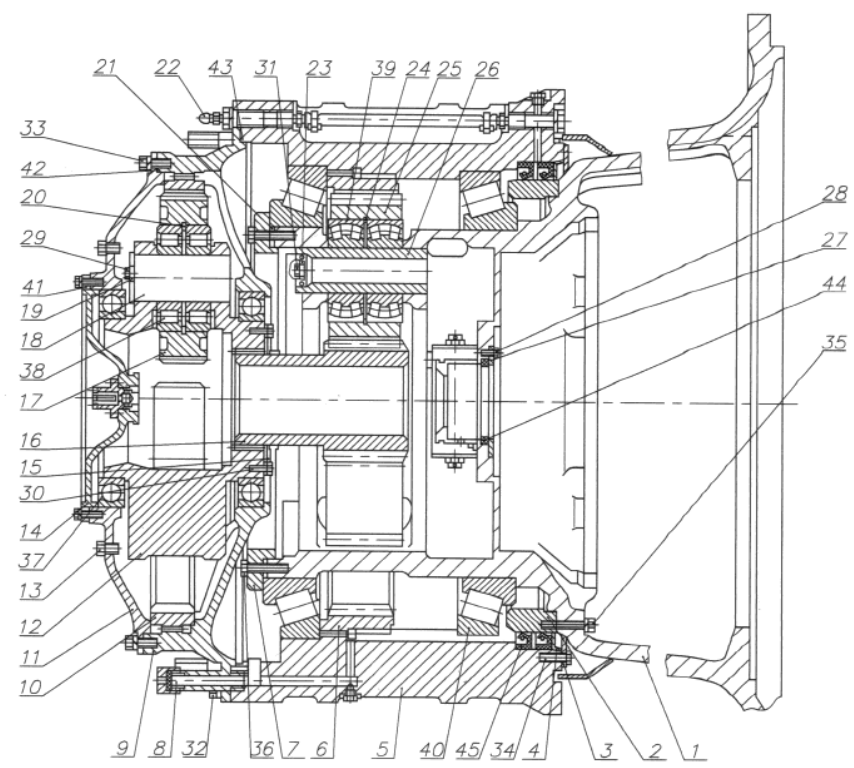

Fig.1.The reducer electric motor-wheel dump trucks BelAZ 75131:

1 - the gear case; 2 - Ring podmanzhetnoe; 3 - clamp; 4 - ring distance; 5 - a nave; 6 - ring gear of the second row; 7 ring resistant; 8 - drain; 9 - a cover of a leading; 10 - the ring gear of the first row; 11 - a cover of the carrier of the first row; 12 - led the first row; 13 - oil level; 14 - a cover of the gearbox; 15 - locking plate; 16 - the sun gear of the second row; 17 - a satellite of the first row; 18 - an axis of satellites of the first row; 19 - locking plate; 20 - a lock ring; 21 - a washer spacer; 22 - oiler; 23 - locking plate; 24 - lock ring; 25 - a satellite of the second row; 26 - an axis of satellites of the second row; 27 - ring; 28 - 36 - bolts; 37 - 40 - bearings; 41 - 43 - o-ring; 44, 45 - collar

The sensor is VK415 TU 37.003.1213-84t. Features: pushbutton, sealed. It can take two positions. Sensors are connected to an electrical circuit with voltage of $12 \mathrm{~V}$. Reducing the length of the rod, we measure by the vernier caliper and a special probe with the thickness of 0.1-1.0 mm the moment of the sensor contact closure. Calibration is conducted 7 times and the we get the average value of the sensor contact closure and its operation - $0.8 \mathrm{~mm}$. To isolate the contacts and to avoid undesirable closure of the circuit, the contacts are covered with non-conductive epoxy-based resins.

The sensor is adjusted as follows:

- Select the gap between the movable contact of the sensor and the outer bearing race by selecting the rod length of the movable contact of the sensor decreasing the length of the movable contact rod by grinding;

- Having tightened the adjusting bolts, screw in the sensor tight into the socket specifically designed for it in the thrust washer, and don't forget to connect it to the mains 
voltage $14 \mathrm{~V}$. When the sensor is screwed in the control lamp should light up, the response time will be $-0.03 \mathrm{~mm} \mathrm{[20] \text {; }}$

- Select the gap by placing shims between the sensor and the thrust washer. The thickness of the shims is $0.1 \mathrm{~mm}$, and the allowable gap - $1 \mathrm{~mm}$. When the sensor is screwed in, the control lamp is on. When the sensor triggers during operation of the dump truck, the control lamp goes out thus warning that the gap of the bearing retainer (Figure 2) exceeded the maximum permissible values.

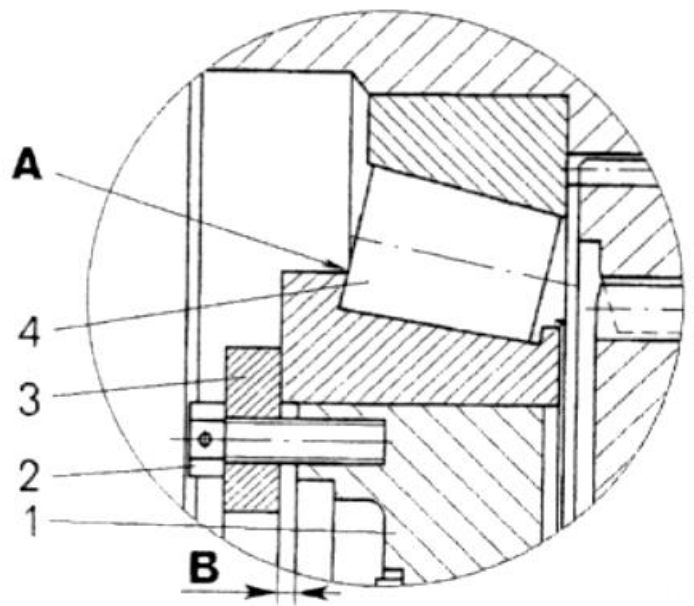

Fig.2. Check the gaps:

1 - gear housing, 2 - adjusting screw, 3 - thrust washer, 4 bearing $\mathrm{A}$ - the installation location of the probe: B - gap

Thanks to this method the motor wheel gear will not operate with the gaps exceeding the allowable limits, and the failure will be prevented.

\section{CONCLUSION}

The developed method allows you to:

1) Control the gap between the bearing and the thrust washer within the normative value;

2) Determine the critical condition of the gap between the bearing and the thrust washer and promptly make adjustments to prevent the failure of the dump truck motor-wheel gear;

3) Eliminate the marginal increase of metal concentration in the oil.

Through this method, the motor-wheel gear will not operate with gaps in excess of the allowable limits that will prevent its failure and will contribute to the following quality improvements:

- Operational control of dump truck condition;

- Continuous monitoring of the condition of gears during operation; longer intervals between scheduled maintenance and repair;

- Reduction of unplanned machinery downtime equipment; a decrease in the current repair costs;

- Protection of quarry dump trucks from accidents (in case of a sudden failure of motor-wheel gear);
-Cost savings in purchasing of new parts and repair work as a result of preventive measures.

\section{REFERENCES}

[1] Artamonov P. V. Programma dlya avtomatizacii rascheta dolgovechnosti nesushchih metallokonstrukcij kar'ernyh avtosamosvalov, na osnove dannyh sputnikovoj navigacionnoj sistemy pozicionirovaniya GPS [Program to automate the calculation of durability of bearing metal mining dump trucks, based on data from GPS satellite navigation positioning system]. / Vestnik Kuzb. gos. tekhn. univ. 2012. \# 3. p. 40-41.

[2] Bazhenov Yu. V. Osnovy teorii nadezhnosti mashin: uchebnoe posobie [Fundamentals of machine reliability theory]. - Moskva: FORUM, 2014. $320 \mathrm{~s}$.

[3] Boyarshinov A.L., Stukanov V.A. Nadezhnost' i tekhnicheskaya diagnostika avto-transportnyh sredstv: uchebnoe posobie [Reliability and technical diagnostics of vehicles]. - Moskva: FORUM, 2015. $240 \mathrm{~s}$.

[4] Goeva V. V., Grishin N. E., Kazakov S.S., Kochenov V.A. Modernizaciya proizvodstva, forsirovanie DVS, dolgovechnost' i iznosostojkost' detalej [Modernization of production, forcing the internal combustion engine, durability and wear parts]. / Vestnik Nizhegorodskogo gosudarstvennogo inzhenerno-ehkonomicheskogo instituta. 2013. \# 10. p. 40-46.

[5] Koniushevskii A.V., Poliakov Al. Af., Poliakov Ar. Al. The influence of dynamic parameters on pressures in parts of mechanical spatial hinged system / Gornyi Zhurnal. 2015. No.8. p. 134-137.

[6] Kuz'min N. A., Borisov G. V. Nauchnye osnovy processov izmeneniya tekhnicheskogo sostoyaniya avtomobilej [Scientific bases of processes of change in the technical condition of vehicles]. Nizhnij Novgorod: Nizhegorod. gos. tekhn. univ. im. R. E. Alekseeva, 2012. $270 \mathrm{~s}$.

[7] Kupriyanov N. S. Nadezhnost', kachestvo, dolgovechnost' [Reliability, quality, durability]. / Russkij inzhener. 2009. \# 23. p. 117.

[8] Mahalov M. S. Metodika ehksperimental'nyh issledovanij ciklicheskoj dolgovechnosti detalej mashin uprochnennyh razmernym sovmeshchennym obkatyvaniem [Methods of experimental studies of the cyclic durability of hardened dimensional combined torsion machine parts]. / Vestnik Kuzb. gos. tekhn. univ. 2009. \# 3. p. 48-52.

[9] Ogorodnov S. M., Zezyulin D. V., Makarov V. S., Tumasov A. V. Obosnovanie metodov resheniya zadachi ocenki ustalostnoj dolgovechnosti detalej i uzlov pod-veski avtomobilej [Justification assessment methods for solving the problem of fatigue life of parts and components car suspension]. / Sovremennye problemy nauki obrazovaniya. 2013. \# 4. p. 1-9.

[10] Trukhanov V. M. Gradual failure model / Journal of Machinery Manufacture and Reliability. -2015 . No.3 p. 254-256

[11] Faskhiev H. A. Proektirovanie detalej transportnyh sredstv po normativnoj stendovoj dolgovechnosti [Design details of the vehicles at standard bench durability]. / Vestnik Ufimskogo gosudarstvennogo aviacionnogo tekhnicheskogo universiteta. 2013. \# 4. Tom 17.p. 44 55.

[12] Yah'ev N. Ya. Osnovy teorii nadezhnosti i diagnostika: uchebnik [Fundamentals of reliability and diagnostics theory]. - Moskva: Akademiya, 2009. - $256 \mathrm{~s}$.

[13]Bershtejn A. I., Cherednik A. G. Problemy tekhnicheskoj ehkspluatacii toplivnoj apparatury dizel'nyh dvigatelej avtomobilej [Problems of technical operation of diesel engine fuel equipment car]/ / Mezhdunarodnyj zhurnal prikladnyh i fundamental'nyh issledovanij. 2015. \# 8. p.429-432.

[14] Gassel'berg V. S., Zaporozhec A. V. Diagnostika dvigatelej vnutrennego sgoraniya avtomobilej po vibroakusticheskim parametram [Diagnosis of internal combustion engines of automobiles for sound and vibration parameters]. / Vestnik Astrahanskogo gosudarstvennogo tekhnicheskogo universiteta. 2007. \# 2. - p. 72-74

[15] Goncharov A. A., Goncharov N. S. Sovershenstvovanie metodik diagnostirovaniya datchika kisloroda avtomobil'nyh dvigatelej [Perfection of a technique of automobile engines oxygen sensor 
diagnosis]. / Vestnik Orenburgskogo gosudarstvennogo universiteta. 2014. \# 10. - p. 236-240.

[16]Kalimullin R. F., Kovalenko S. Yu. Koncepciya resursosberegayushchej ehkspluatacii avtomobil'nyh dvigatelej [The concept of resourcesaving operation of car engines]./ Vestnik Saratovskogo gosudarstvennogo tekhnicheskogo universiteta. 2013. \# 2. p. 29-34.

[17] Panachev I. A., Kuznecov I. V. Predel'no-dopuskaemye parametry uslovij ehkspluatacii bol'shegruznyh avtosamosvalov po kriteriyu ehffektivnosti raboty dvigatelya [Limit parameters of heavy dump trucks operating conditions by the criterion of efficiency of the engine]. / Vestnik Kuzb. gos. tekhn. univ. 2015. \#1. p. 34-37.

[18]Vlasov Yu. A., Tishchenko N. T. Issledovanie processov iznashivaniya reduktorov motor-koles avtosamosvalov BELAZ po parametram rabotayushchego masla [Study of wear processes geared wheel gearboxes BelAZ dump trucks for the parameters of working oil]. / Vestnik Kuzb. gos. tekhn. univ. 2012. \#1. p. 1-5.
[19]Bogdanov S. V., Horeshok A. A., Kudrevatyh A. V. Opredelenie tekhnicheskogo so-stoyaniya reduktora motor-kolesa avtosamosvalov metodom ehmissionnogo spek-tral'nogo analiza masla na osnove dinamiki temperatury [Definition of the technical condition of the gear motor-wheel dump method of emission spectral analysis based on oil temperature dynamics]. / Gornoe oborudovanie i ehlektromekhanika. 2009. \# 5. p. 50-52

[20] Horeshok A. A., Kudrevatyh A. V. Metod kompleksnogo diagnostirovaniya reduktorov motor-koles kar'ernyh avtosamosvalov (na primere OAO UK «Kuzbassrazrezugol'») [The method of diagnosing complex motor-gear wheel-pit dump trucks (for example, «KRU» JSC Coal Company)]. / Gornaya promyshlennost'. 2010. \# 5. p.60-64.

[21]RUPP «Belorusskij avtomobil'nyj zavod» Kar'ernyj samosval BelAZ-75131 i ego modifikacii, rukovodstvo po remontu [Modification and repair manual «Belarusian Autoworks» Dumper BelAZ-75131]. - Zhodino, 2009. 